\title{
Cloning and expression of a Hemocyanin isolated from the centipede Cryptops iheringi
}

Kariny P. Cruz'; Milton Y. Nishiyama Jr ${ }^{3}$; Inácio de Loiola Meirelles Junqueira de Azevedo ${ }^{3}$; Geraldo Santana Magalhães ${ }^{1}$; Lhiri Hanna Alves De Lucca Shimokawa-Falcão'. ' 'Laboratory of Immunopathology, Butantan Institute, Brazil. 'Post-Graduation Toxinology, Instituto Butantan, Brazil. ${ }^{3}$ Special Laboratory of Applied Toxinology, Instituto Butantan, Brazil.

\section{INTRODUCTION}

In this work a transcriptomic analysis of the $C$. iheringi venom gland was performed to obtain a profile of the toxins of this species. In addition, the crude venom was subjected to mass spectrometry analysis to establish an association between unknown sequences. These approaches for the construction of a general profile of the venom gland expression of this species led to the he identification of a Hemocyanin ( $\mathrm{Hc}$ ) subunit.

Hemocyanins are copper-containing, respiratory proteins that occur in the haemolymph of many arthropod species. Here, we report the presence of $\mathrm{Hc}$ in the chilopode Myriapoda C. iheringi. Such respiratory proteins have long been considered unnecessary in Myriapoda, due to its tracheal systems.

These respiratory proteins are potent immunogens, which induce the synthesis of large amounts of specific antibodies. Studies pointed out its interaction with polymorphonuclear monocytes and lymphocytes and in vitro tests have shown a potential anticancer activit, with in vitro significant inhibition of the growth of cancerous strains of the breast, pancreas and prostate. Currently scientific data is mostly limited to the study of native $\mathrm{Hc}$ of $M$. crenulata molluscs, therefore, the biotechnological potential of Hcs isolated from centipedes is still unexplored.

\section{METHODS}

The Hc subunit sequence was synthesized with codon optimization for bacteria expression and the protein expressed as inclusion bodies. Refolding attempts provided soluble forms of $\mathrm{Hc}$.

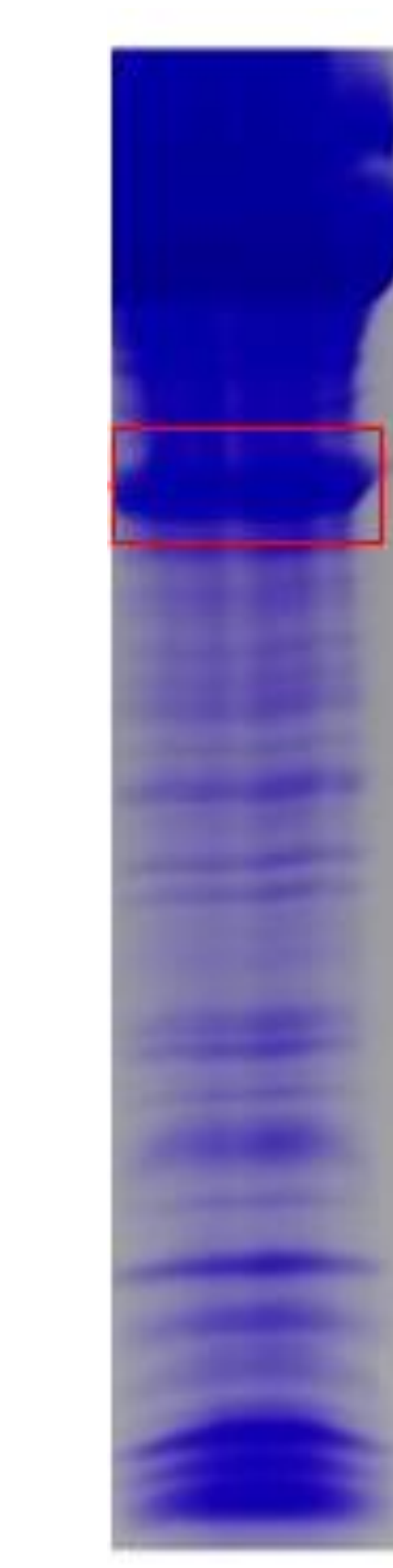

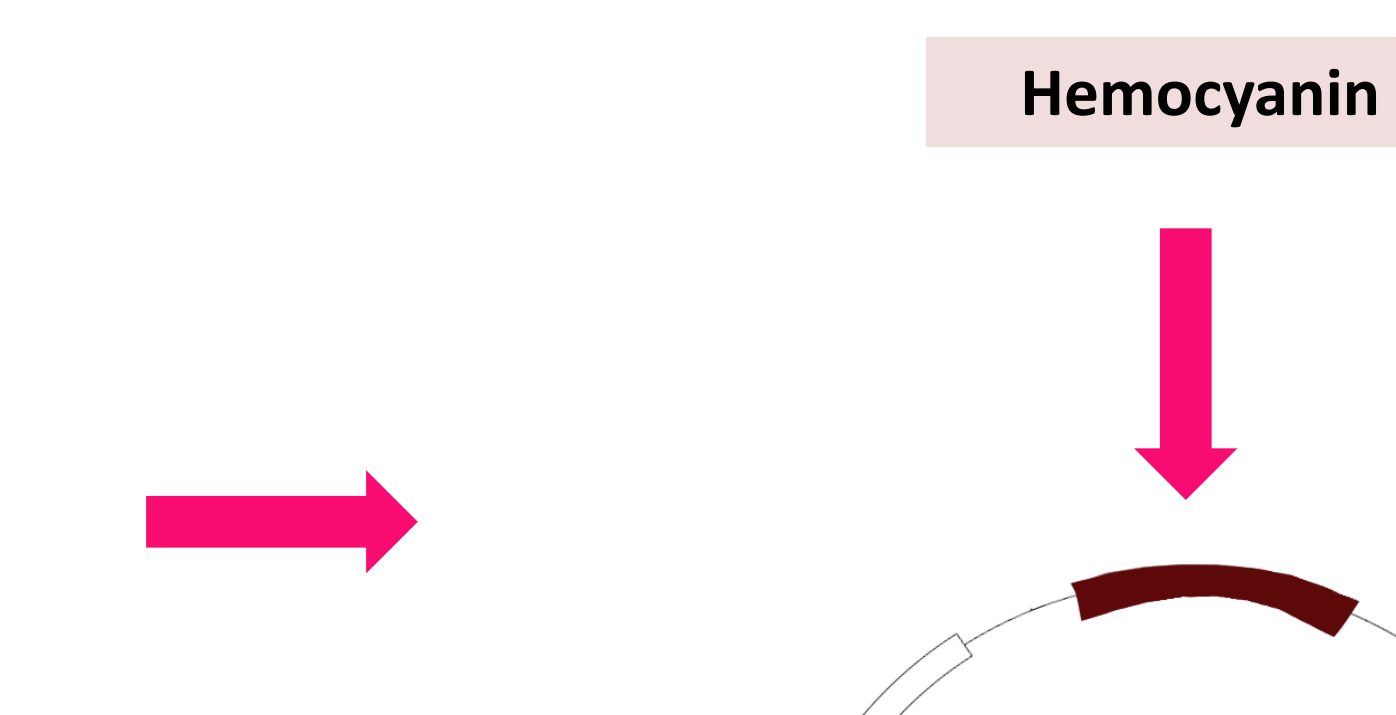

$$
\text { PET24b (+) }
$$

年

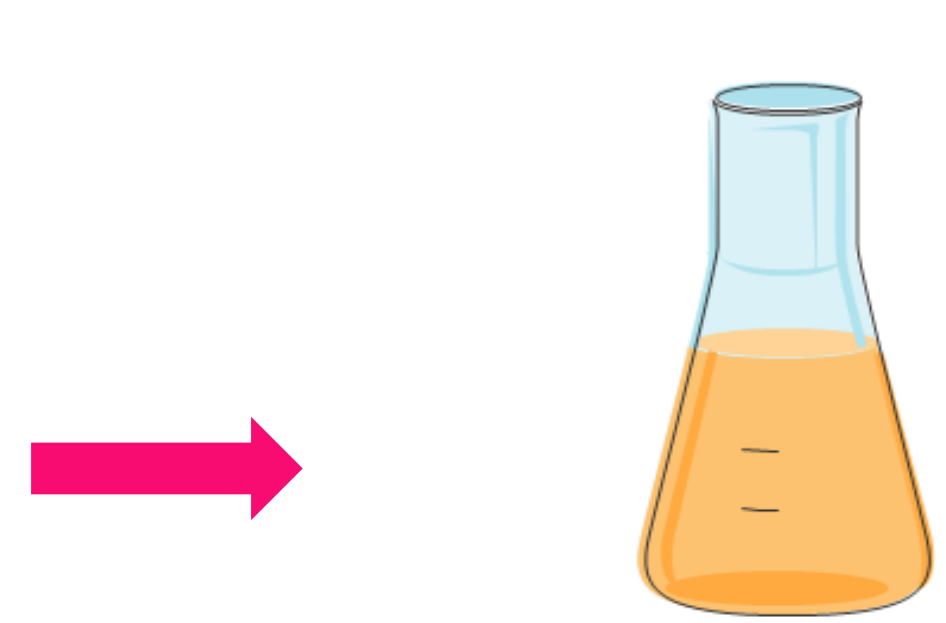

Transformation and expression in BL21-star bacteria

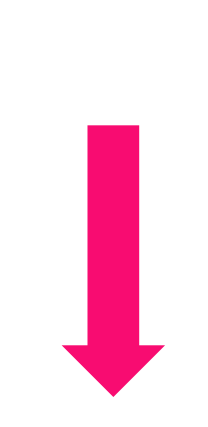

C. iheringi venom 10ug
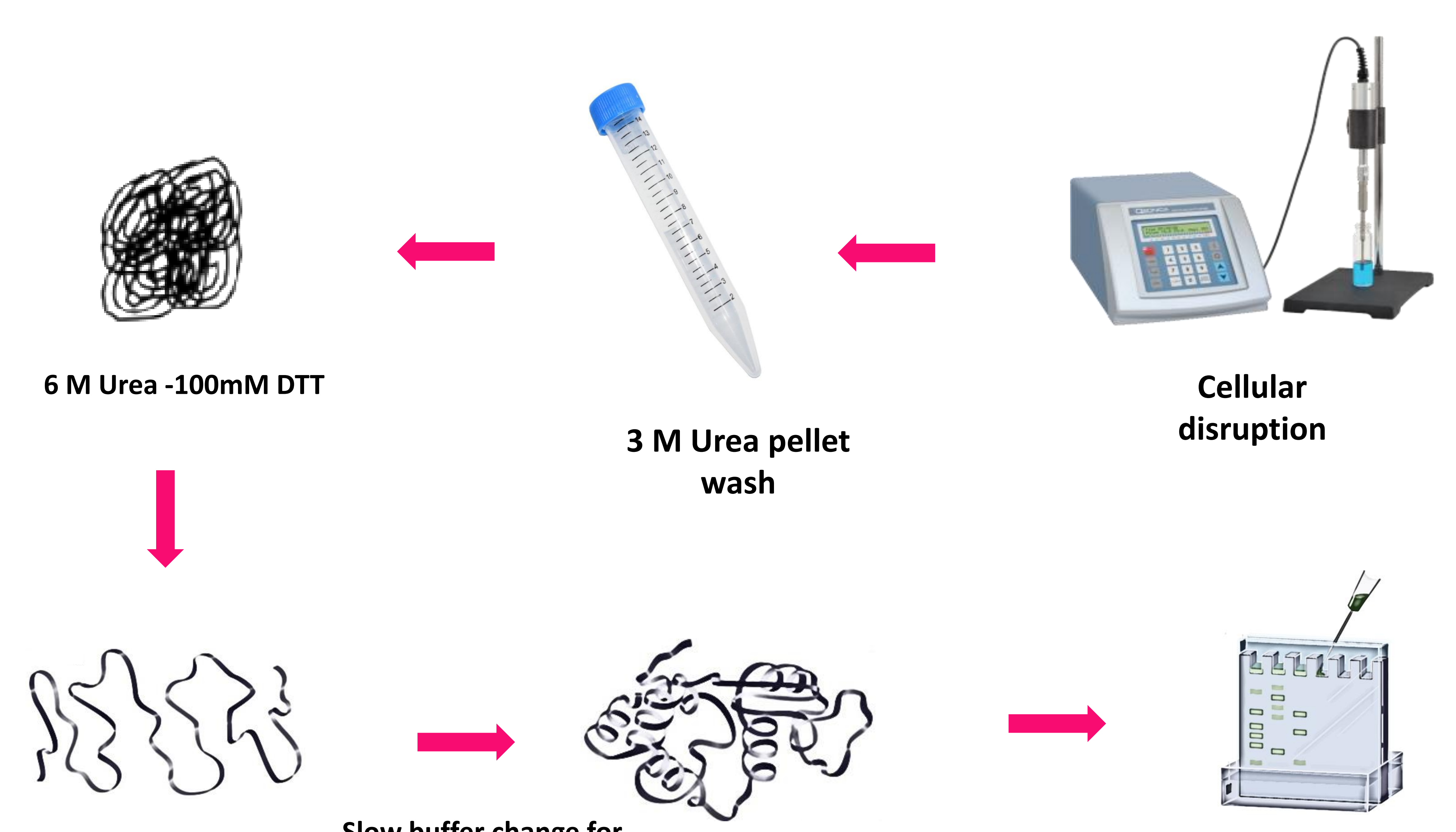

SDS-PAGE

\section{RESULTS AND CONCLUSION}

The Hc sequence have a $76 \mathrm{kDa}$ range. The $\mathrm{Hc}$ subunit sequence was succecefuly expressed as inclusion bodies. Refolding attempts provided soluble forms of $\mathrm{Hc}$ that now will be used to explore its anticancer activit.

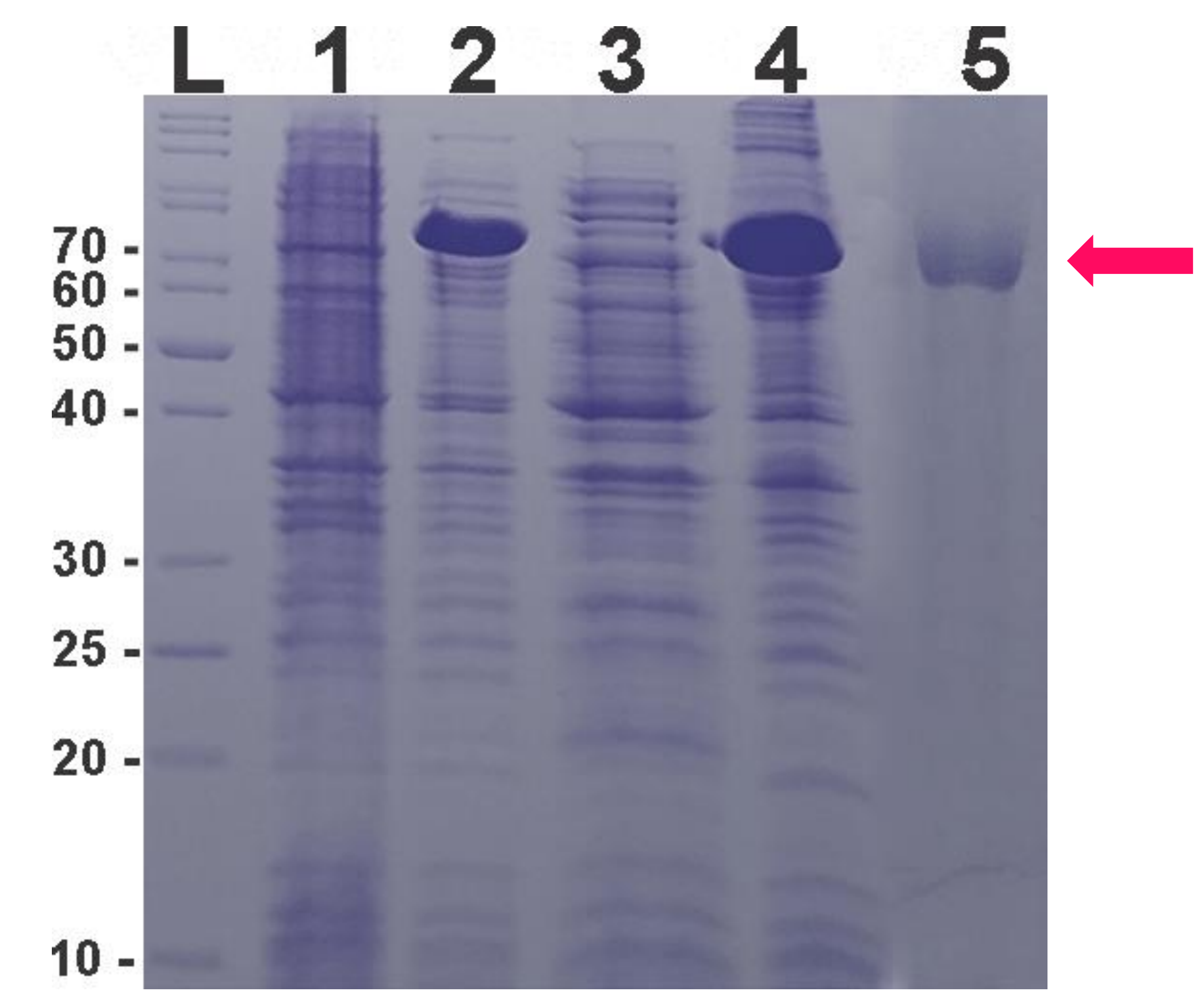

SDS-PAGE $12 \%$ containing the expression and refolding of Hemocyanin after $4 \mathrm{~h}$ of $1 \mathrm{mM}$ IPTG induction. Stained with Comassie blue .

L- Ladder, 1- bacterial pellet before 1mM IPTG induction, 2 - bacterial pellet after IPTG induction, 3- supernatant, 4- Refolded protein.

\section{REFERENCES}

M. Jürgen., M. Arne., M. G. Andreas., R. Judith, G. Wolfgang., D. Frank., 2009. 10- $\AA$ CryoEM Structure and Molecular Model of the Myriapod (Scutigera) $6 \times 6$ mer Hemocyanin: Understanding a Giant Oxygen Transport Protein. Elsevier.

S. Samantha., H. Nadja ., F. Rosa., P. Christian., B. Thorsten., 2018. Diversity, evolution, and function of myriapod hemocyanins. BMC Evolutionary Biology.

K. C. T. Riciluca., A. C. Borges.,J. F. R. Mello., U. C. de Oliveira.,D. C. Serdan., A. Florez-Ariza.,E. Chaparro.,M. Y. NishiyamaJr., A. Cassago.,I. L. M. Junqueira-de-Azevedo., M. van Heel., P. I. Silva Jr.,R. V. Portugal., 2020. Myriapod haemocyanin: the first threedimensional reconstruction of Scolopendra subspinipes and preliminary structural analysis of S. viridicornis. Open Biology. 